\title{
Final
}

\section{Employment, flexibility and labour market practices of domestic and MNC chain luxury hotels in Australia: Where has accountability gone?}

\author{
Michael Davidson \\ Department of Tourism, Leisure, Hotel and Sport Management \\ Chris Guilding \\ Department of Tourism, Leisure, Hotel and Sport Management
}

and

Nils Timo

Department of Management

Griffith Business School

Griffith University

Australia

\author{
Contact address for correspondence: \\ Nils Timo \\ Griffith Business School \\ Department of Management, \\ Griffith University, \\ Gold Coast Campus, \\ P.M.B. 50, \\ Australia \\ Gold Coast Mail Centre Qld. 9726 \\ Email:n.timo@griffith.edu.au
}

We are grateful to the hotel managers and employees who participated in the study. We also acknowledge the insightful and constructive comments of the anonymous reviewers, errors and omissions remain the responsibility of the authors. 


\title{
domestic and MNC chain luxury hotels in Australia: Where has accountability gone?
}

\begin{abstract}
This study investigates employment and labour market practices based on observations derived from a two-phased empirical study that has yielded quantitative and qualitative sets of empirical data from luxury 4-5 star luxury domestic and multinational corporation (MNCs) hotels located in Australia's Brisbane-Gold Coast corridor. The research had two phases: a quantitative phase comprised an employee relations survey that sought data on operational employee and management demographics, wage levels, gender, skill formation and working conditions; and a qualitative phase involved interviewing fourteen hotel human resource managers. The survey data highlights a persistence of gendered, low waged and segmented labour markets dominated by flexible forms of labour suggesting that HR accountability structures in hotels remain weak. This is despite an apparent growth in employee educational levels and hotel training activity suggesting the possibility at least of growing professionalism. It is noted that in this labour market which we find is dominated by a ready supply of labour with low levels of union activity, increasing human capital levels have not translated into upward pressure on employee and managerial wages. This deficiency is likely to inhibit efforts to improve the delivery of HRM practices that in turn suggest that neither MNC nor domestic hotels have the types of labour market pressures that engender secure, long term and high commitment employment policies that are more conducive to HRM innovation.
\end{abstract}

Key words: Multinational hotels; Employee relations practices; Hotel turnover; HR accountability; Workforce flexibility

\section{Introduction}

This aim of this article is to report and reflect upon the results from data drawn from two studies which examined the relationships between employment and labour market practices of selected domestic and multination corporation (MNC) hotels operating in Australia. The primary focus was on assessing the extent to which these hotels have adopted accountability practices that encourage innovative HRM and employment practices that address management and labour problems in the industry. Much of current influential HRM literature suggests a link between the pace of HRM innovations and adoption of HR accountability mechanisms for addressing staffing and labour market problems (Barney, 1995; Orlando, et al. 2001; Storey et al. 2002). Enhancing our understanding of managerial practices and labour markets in the hotel industry is important in the face of two decades of intense growth and significant internationalization of this industry (Littlejohn, 1997).

The hotel industry is a major component of world tourism which accounted for $10 \%$ of global employment (ILO, 2001) and \$US \$4.4 trillion of world wide economic activity in 1997 (World Bank, 1997). The World Tourism Organization (WTO) estimates that global tourism is responsible for creating approximately 192.2 million jobs (or one in every 12.4 jobs) in 1995 growing to 251.6 million jobs or one in every 11 jobs by 2010 (WTO, 1996). There are now over 40 large hotel brands operating in 
Australia employing about 513,000, mostly young people, with a gross domestic product amounting to over A $\$ 20$ billion (Tourism Forecasting Council, 2001).

Understanding how firms structure and account for labour practices have been at the core of HRM debates from the early work of Kerr et al. (1964) on industrial organization and creation of internal labour markets through to Stone's (1974) early work on the importance of supervisory mechanisms and job ladders in the steel industry through to Atkinsons' (1984) work on new employment patterns. Debates about trends in management. labour practices and labour markets have generally been located within arguments about 'flexible firm' or 'core-periphery' employment strategies. However, here there is neither agreement on conceptualization nor nomenclature (see Pollert, 1988; Stephen et al. 1994). The way labour is managed in the hotel industry has generated considerable debate in the academic hotel literature and attention has been directed towards describing the characteristics of hotel labour markets and managerial practices. This has resulted in the categorization of a range of contingent or a-typical forms of employment practices (see for example, Deery and Jago, 2002). Whilst these identify different patterns of labour use, they do not explain how such patterns come about.

There is an emerging research agenda that moves beyond the core-periphery view that focuses on the role of HR innovation and transfer of HR practices between firms, especially as between domestic and MNC firms exploring on the one hand, links between workforce employment and human capital practices, and on the other hand, firm profit and cost minimisation strategies (Huselid et al. 1997; Lepak and Snell, 1999; Wright and Boswell; 2002). This literature increasingly emphasizes the link between HR innovation and firm performance and look to MNC firms for support (Barney, 1995; Orlando, et al. 2001). Trends evident in this new research agenda include assessing the extent to which MNCs are conduits for transmitting 'new' or innovative HRM/employment relations practices across national borders (Ferner and Quintanilla, 1998; Lepak and Snell, 1999; Sparrow et al. 1994) and the effectiveness of national labour regulatory regimes and labour standards in moderating MNC employment practices (Lane, 1991; Ramsay, 1997). Convergence explanations postulate that employment strategies and employment practices are coalescing towards a 'common employment pattern' (Kerr et al. 1960; Pfeffer, 1994) whereas divergence explanations suggest that firms' employment strategies and practices are predominantly shaped by the unique characteristics of the domestic environments in which they operate (Hofstede, 1991; Rowley and Benson, 2002).

Our understanding of HRM practice in large domestic and MNC hotels remains limited to a handful of studies conducted over the past decade (e.g., in New Zealand: Haynes and Fryer, 1999; in Australia: Timo, 1999; Timo and Davidson, 2002; Knox, 2002; and in the United Kingdom: Price, 1994; Harrington and Akehurst, 1996; Lucas, 1996; Kelliher and Johnson, 1997; Hoque 1999, 2000; McGunnigle and Jameson, 2000). Hotel employment is often portrayed as the archetype of a 'flexible and precarious' form of labour engagement (Guerrier and Lockwood, 1989; Lucas, 1996; Timo, 1999), with internal and external labour markets much more porous than previously thought (Price, 1994; Deery and Jago, 2002). Researching hotel management and labour practices are not without challenges as there is little consensus on what defines HRM or labour management in the hotel context (McGunnigle and Jameson, 2000). Hoque (2000) suggests that it is only the larger 
hotels with established HRM departments that are likely to experiment with 'new' or innovative HRM practices while smaller hotels remain a 'black hole'. Globally, cost minimization employment strategies appear to dominate hotel management strategies with evidence of Atkinson-type balkanized and low pay labour markets connected to casual and temporary forms of labour being the norm rather than exception (Price, 1994; ILO, 2001: 49).

The above research issues underline the relevance of the two studies reported herein. The paper is structured as follows: the next section outlines the research methodology. We then trace the contours of the Australian domestic and MNC luxury $4-5$ star hotel industry. Subsequently key survey findings that focus on labour flexibility, wages, training, gender and turnover are presented and discussed in the context of HRM practice. The article concludes with a discussion of the findings and suggestions for future research.

\section{Research method}

The two studies are based on the Brisbane-Gold Coast corridor in Queensland, Australia. Queensland accounts for 374 (or 30.9\%) of all Australian graded 4 star hotels and 42 (or 36.2\%) of all Australian graded 5 star hotels (ABS, 2004c, Tables 3 and 6) with almost half clustered in the Brisbane-Gold Coast corridor which accounts for $40.4 \%(n=17)$ of all large Queensland 5 star hotels (ABS, 2004c) thereby providing an excellent research site for the study. The term "luxury hotel" is underdefined; however it implies hotel accommodation of a high standard and the provision of fine dining, 24 hour room service, valet parking, dry cleaning, business facilities, and well trained staff.

The study draws on two data sets. The first is a quantitative data source drawn from an employee relations survey of labour market flexibility, wages, training and working conditions of luxury 4-5 star MNC and domestic hotels located in sample area. This survey was designed to provide a profile of MNC hotel employment characteristics that include age, gender, employment status, working time arrangements, skill formation, and labour turnover. Data was collected during 20002001 using both a managerial and an operational employee questionnaire. Following a briefing, each hotel's HRM department was assigned responsibility for distributing all up 4,034 questionnaires that were distributed with wage slips, so the survey data can be seen as providing a 'snapshot' of employee and employment factors at one point in time. This sampling methodology yielded 1,792 completed questionnaires from operational employees and 145 completed questionnaires from managers. It is recognized that a limitation is the small sample of domestic hotels (3 in all) making comparison with MNC hotels difficult, however, useful data was collected from interviews that shed light on differences and comparisons that are discussed further on.

The second involves a qualitative data source involving follow up transcribed interview data collected in meetings with 14 HRM hotel managers. The 14 HRM hotel managers that acted as subjects in the interview phase of the study worked in large four to five star hotels (eight MNCs and six domestically managed). Meetings with the managers followed a semi-structured format, ranged in duration from 45 to 75 minutes and were conducted in 2003. The interviews focused on accountability systems for managing labour turnover covering broader HRM practices and should be 
seen as providing data that supplements the insights derived from the survey data collected.

\section{Findings and discussion}

Demographic characteristics:

Survey responses were broadly evenly split between gender, with female employees accounting for $48 \%$ and male employees accounting for $52.0 \%$. However, there was a clear gender difference at the managerial level with the number of male managers (65.5\%) exceeding female managers (34.5\%) by 31\%. Whilst this managerial gender ratio may be not that atypical of other industries, the continuation of this senior level gender imbalance within the four and five star hotel sector, appears noteworthy, particularly in light of the number of female operational (or line) staff members attracted to the industry. The distribution of the survey sample's age is presented in Table 1. This provides a strong indication of the relatively high degree to which large hotels attract a relatively young workforce.

Table 1 Age profile of operational employees and managers

\begin{tabular}{|lcr|}
\hline Operational Employees & Frequency & \%* \\
\hline $15-24$ years & 528 & 30.5 \\
$25-34$ & 603 & 34.8 \\
$35-44$ & 340 & 19.6 \\
$45-54$ & 212 & 12.2 \\
$55-64$ & 45 & 2.6 \\
$65+$ & 3 & 0.2 \\
Total & $\mathbf{1 7 9 2}$ & $\mathbf{1 0 0 . 0}$ \\
\hline Managers & & \\
$15-24$ years & 3 & 2.1 \\
$25-34$ & 58 & 40.0 \\
$35-44$ & 55 & 37.9 \\
$45-54$ & 22 & 15.2 \\
$55-64$ & 6 & 4.1 \\
$65+$ & 1 & 0.7 \\
Total & $\mathbf{1 4 5}$ & $\mathbf{1 0 0 . 0}$ \\
\hline
\end{tabular}

No missing data

Overall, the demographic data collected reveals the luxury hotel labour force to be nearly equally divided between males and females, and relatively young with the majority of operational employees aged 34 or less. The majority of the operational employees or $65.3 \%$ are to be found in the 15-34; $30.5 \%$ between 15 and 24, and $34.8 \%$ \% between 24 and 34 years of age group. Consistent with this, managers appear to be heavily biased towards younger age groups of the working population. Most managers or $40.0 \%$ are in the $25-34$ year age group, with $77.9 \%$ of the sample of manager's falling within the 25-44 years age group category. Women remain under-represented in management ranks as approximately two thirds of the managers surveyed were male. Interviewees suggest that a reason for the lack of female hotel managers is that management careers are shaped through higher revenue departments that are traditionally male dominated (e.g. gaming, finance/accounts, trade occupations). Although this signifies an under-representation of female hotel managers in absolute terms, in relative terms the luxury hotel sector has a higher proportion of female managers, as females hold only $20 \%$ of managerial positions across all Australian industrial sectors (ABS, 2000b). 


\section{Education and training:}

The 'youthfulness' of the labour market suggests that it attracts a number of younger persons seeking work and careers, many of these have some form of educational attainment. . Table 2 provides an overview of the educational levels of the sample. Respondents to the survey were asked to indicate their highest level of formal education achieved. Contrary to earlier industry surveys (Norris, et al. 1995), our survey found the luxury hotel sector to be well qualified, with over $64.9 \%$ of operational staff holding some form of post-secondary education level qualifications and above and as compared to only 51\% in all industry average (ABS, 2004a and 2004b). Managers also appear to be becoming increasingly educated with $51.1 \%$ holding an associate diploma level, apprenticeship or other post school qualification and $23.1 \%$ holding a university degree.

Table 2Educational level of operational employees and managers
\begin{tabular}{|lcc|}
\hline Operational Employees & Frequency & $\mathbf{\%}^{*}$ \\
Secondary & 601 & 35.1 \\
Post-secondary & 261 & 15.3 \\
Apprenticeship & 233 & 13.6 \\
Assoc. Dip & 279 & 16.3 \\
Degree & 284 & 16.6 \\
Post Grad. & 53 & 3.1 \\
Total & $\mathbf{1 7 9 2}$ & $\mathbf{1 0 0 . 0}$ \\
\hline & & \\
Managers & & \\
Secondary & 29 & 20.3 \\
Post-secondary & 14 & 9.8 \\
Apprent'ship & 23 & 16.1 \\
Assoc. Dip & 36 & 25.2 \\
Degree & 33 & 23.1 \\
Post grad. & 8 & 5.6 \\
Total & $\mathbf{1 4 5}$ & $\mathbf{1 0 0 . 0}$ \\
\hline
\end{tabular}

$* 4.5 \%$ of operational employees

$* * 1.4 \%$ of managers

It is useful to consider the findings on educational levels as reported in Table 2 with the incidence of training shown in Table 8. First, since the mid 1980's, the Australian hospitality industry has established a series of training modules and competency levels linked to occupational classifications with each level accredited under the Australian Qualification Framework (AQF). Accredited training is conducted under the auspices of Tourism Training Australia, which is a government appointed industry training advisory board, together with the Australian Hospitality Review Panel (AHRP) which is responsible for accrediting workplace training courses. Courses and competencies are established according to set curricula delivered across various educational and training institutions and these cannot be advertised as approved tourism courses without AHRP approval. In light of these developments, it is to be expected that hotel training levels have increased significantly over the last 20 years.

Second, a couple of factors affecting the demographic nature of the sample can be conjectured. Firstly, for more than a decade the Brisbane-Gold Coast corridor has been the fastest growing area in Australia and this expansion might well be attracting 
young educated workers. Secondly, there are several universities located in northern New South Wales and South East Queensland that provide specialist studies in hospitality and tourism management. These universities are providing a significant steady stream of graduates with aspirations for a career in the hospitality industry.

\section{Job status and tenure:}

A significant factor shaping the contours of the labour market is employment status and job tenure. There is a preponderance of a-typical forms of employment that shape hotel labour markets according to a core-periphery with a greater propensity for casualisation, high turnover and multiple job holding (Timo, 1999). For the entire hotel sector, more than half of all hotel employment is provided on a casual or contingent basis; a statistic that well exceeds OECD average (Norris et al. 1995; Timo, 1999). A separate industry survey of 4-5 star Queensland hotels conducted in 2001 - 2002 (covering mostly MNCs), showed an average turnover rate of 44.9\% (unpublished hotel survey, Daikyo, March 2003). Our survey confirms the contingent and numerically flexible nature of the hotel workforce. Table 3 reports the nature of employment engagement for operational employees. Most of the employees (60.6\%) held a fulltime position. A relatively low percentage (10.6\%) were part time (though industry parlance tends to lump terms casual and part-time into a single category), however a significant sector of the hotel workforce experiences highly compromised levels of job security as more than a quarter (i.e., 28.8\%) of employees are employed on a casual basis. It should be noted that the data reported in Table 3 can be expected to be highly seasonally dependent. Had the survey been conducted during the hotels' busy season (in Australia this is the Summer/Christmas season covering September through to January) there would have been a much greater incidence of casual employment.

Table 3 Nature of employment engagement for operational employees
\begin{tabular}{|ccc|}
\hline Operational Employees & Frequency & \%* \\
Full time & 1041 & 60.6 \\
Part time & 183 & 10.6 \\
Casual & 495 & 28.8 \\
Total & $\mathbf{1 7 9 2}$ & $\mathbf{1 0 0 . 0}$ \\
\hline 4.1 \% &
\end{tabular}

The survey also sought information on the sample's organizational (length of employment with hotel) and job tenure (length of employment in present job). The findings with respect to organizational tenure (length of employment with current employer) are reported in Table 4 . The data indicates that $56.5 \%$ of the operational employee respondents had been employed with their existing employer for two or less years; less than a quarter or $23.2 \%$ had been employed by their current employer for 3-5 years with only $18.4 \%$ of employees who indicated employment with their current employer for six or more years. A similar finding was made for hotel managers with $48.3 \%$ of hotel managers having been employed with their existing hotel for two years or less and approximately a quarter (24.8\%) having had the same employer between 3-5 years. Only 26.9\% of hotel managers indicated having been employed by their current employer for six or more years.

Table 4 Organizational tenure for employees and managers 


\begin{tabular}{|lrr|}
\hline Employees & Frequency & \%* \\
$0-2$ years & 1017 & 56.5 \\
$3-5$ & 403 & 23.2 \\
$6-8$ & 186 & 10.7 \\
$9-11$ & 95 & 5.5 \\
$12-14$ & 27 & 1.6 \\
$15-17$ & 11 & 0.6 \\
Total & $\mathbf{1 7 9 2}$ & $\mathbf{1 0 0 . 0}$ \\
Managers & & \\
$0-2$ & 70 & 48.3 \\
$3-5$ & 36 & 24.8 \\
$6-8$ & 26 & 17.9 \\
$9-11$ & 9 & 6.2 \\
$12-14$ & 4 & 2.8 \\
Total & $\mathbf{1 4 5}$ & $\mathbf{1 0 0 . 0}$ \\
\hline
\end{tabular}

$* 3.0 \%$ of operational employees

$* * 0.0 \%$ of managers

Table 5 presents findings with respect to the length of time respondents had been the incumbent to their position at the time the survey was undertaken. When the job tenure findings are considered, it becomes apparent that the luxury hotel labour market is fragile with a majority of operational employees having only held their jobs for two years or less (56.5\%) with only $23.2 \%$ of the operational employees having held their current position for $3-5$ years. This signifies that $79.7 \%$ of the operational employees had held their position for five or less years. A similar picture appears for hotel managers with nearly half of managers or $48.3 \%$ having held their positions for two years or less or $73.1 \%$ of managers having held their positions for five years or less.

Table 5 Job tenure for operational employees and managers

\begin{tabular}{|lrr|}
\hline Operational Employees & Frequency & \%* \\
$0-2$ years & 1134 & 65.7 \\
$3-5$ & 358 & 20.7 \\
$6-8$ & 122 & 7.1 \\
$9-11$ & 79 & 4.6 \\
$12-14$ & 19 & 1.1 \\
$15-17$ & 14 & 0.8 \\
Total & $\mathbf{1 7 9 2}$ & $\mathbf{1 0 0 . 0}$ \\
Managers & & \\
$0-2$ years & 94 & 64.8 \\
$3-5$ & 32 & 22.1 \\
$6-8$ & 12 & 8.3 \\
$9-11$ & 2 & 1.4 \\
$12-14$ & 5 & 3.4 \\
Total & $\mathbf{1 4 5}$ & $\mathbf{1 0 0 . 0}$ \\
*3.7 \% of operational employees & \\
**0.0\% of managers & &
\end{tabular}

There may be a number of reasons accounting for this labour instability. First, for many operational employees, hotel work is often closely connected to life style. 'Play and work' may attract staff who see work in the industry as glamorous due to the tourism connection. Second, low skill barriers to entry, seasonality, low pay, and the 
persistence of non-standard forms of employment create conditions for job instability, turnover, and multiple job-hopping. Third, casual employment is highly mobile and irregular as casual ports of entry can accelerate later transition to part time and full time employment (Timo, 1999; Chalmers and Kalb, 2001). Finally, there are finite job opportunities. For both managers and operational staff, hotel departmentalization can inhibit career development by placing barriers on internal career ladders and upward mobility. This can encourage a culture of frequently changing employers in order to secure career advancement. It is company policy in many of the major national and international hotel chains to 'compel managers to rotate frequently between properties, often every three years' (HRM Director, large MNC hotel, personal communication, $8^{\text {th }}$ April 2001).

Human capital potentially 'walking out the door' is a significant cost factor and quality issue that retards performance and growth. This has HRM implications according to Storey et al.

'...the HR literature tends to, on the whole, to suggest that secure, permanent employment contracts allied to a 'high-commitment' management approach will be necessary or at least advantageous in those cases where a business strategy aspires towards innovation' (2002: 3).

The effect of continuing high staff turnover levels in the industry highlights the lack of effective HRM practices, accountability and managerial systems that, if in place, could better manage staff turnover and human capital loss. The interview data collected suggests that both MNC and domestic hotels lack clearly articulated points of accountability or 'pulse points' for turnover with responsibility for turnover and entry level training being borne financially by the HR department and limited importance attached to the issue in the departments that experience the turnover. One HR manager commented:

'Operating managers are very aware of turnover and very careful with turnover in managing and monitoring it, but yes it's a little bit down the list of priorities'

In addition, most MNC HRM departments in hotels conduct regular exit interviews, however, this data does not appear to be collated and disseminated to departments. This is particularly so when exit interview responses related to unsatisfactory pay or management/supervision issues (such as poor management). Instead of tackling turnover as an organizational wide problem, short term prescriptive measures are adopted such as exit interviewing but without collating the data longitudinally, developing and implementing corrective action, a feature of weak HR accountability structures (Denvir and McMahon, 1992). Departmentalization shifts responsibility horizontally with HRM departments generally only responsible for costs of training and replacements only. Interviewees held a consensus view that most of their HRM expenditure is driven by staff turnover (advertising, replacing and training). A problem noted by the interviewees with respect to how staff turnover might be better managed concerns the fact that some staff turnover is desirable.

Manager interviewees noted that a degree of staff turnover is desirable as it enables an infusion of fresh ideas and can signify the removal of 'dead wood' or de-motivated employees. This signifies that identifying an optimal level of staff turnover is problematical. Clearly, there are political dimensions to this type of data. Departments were found to exercise a high degree of autonomy over staffing and employee 
management issues in direct dealings with employees with HR playing a line advisory role only thereby delegating $\mathrm{HR}$ accountability to a department that does not necessarily see HR as a key competency or function.

\section{Remuneration:}

Table 6 presents an overview of data collected with respect to salary levels. It is evident that the industry continues to provide a low remuneration with $85.7 \%$ of operational employees earning $A \$ 30,000$ or less per annum. Further, $65.4 \%$ of surveyed operational employees earn less than A \$25,000 per annum and less than 1\% earn an annual salary above $\mathrm{A} \$ 50,000$. While the majority of the surveyed managers (60\%) earn less than $\mathrm{A} \$ 49,000$ per annum, it is noteworthy that there is a small outlying group of managers (5.7\%) earning in excess of $\$ 100,000$. It is anticipated that this outlying group would comprise general managers and other members of the senior executive.

Table 6 Gross salary for operational employees and managers

\begin{tabular}{|c|c|c|}
\hline Operational Employees A\$ & Frequency & $\% *$ \\
\hline $0-5,000$ & 80 & 4.8 \\
\hline $6-10,000$ & 94 & 5.6 \\
\hline $11-15,000$ & 156 & 9.3 \\
\hline $16-20,000$ & 232 & 13.9 \\
\hline $21-25,000$ & 531 & 31.8 \\
\hline $26-30,000$ & 339 & 20.3 \\
\hline $31-35,000$ & 145 & 8.7 \\
\hline $36-40,000$ & 53 & 3.2 \\
\hline $41-45,000$ & 22 & 1.3 \\
\hline $46-50,000$ & 2 & 0.1 \\
\hline $50,000+$ & 15 & 0.9 \\
\hline Total & 1792 & 100.0 \\
\hline \multicolumn{3}{|l|}{ Managers } \\
\hline $30-39,000$ & 42 & 30.0 \\
\hline $40-49,000$ & 42 & 30.0 \\
\hline $50-59,000$ & 26 & 18.6 \\
\hline $60-69,000$ & 13 & 9.3 \\
\hline $70-79,000$ & 5 & 3.6 \\
\hline $80-89,000$ & 3 & 2.1 \\
\hline $90-99,000$ & 1 & 0.7 \\
\hline $100,000+$ & 8 & 5.7 \\
\hline Total & 145 & 100.0 \\
\hline
\end{tabular}

$* 3.7 \%$ of operational employees

**3.4\% were excluded.

At the time of the survey, the exchange was A\$1.00 = US\$ 0.62

The last major survey of hotel wage levels by Norris et al. (1995: 57-58) found that hotel workers (excluding maintenance engineers and chefs) were generally young and lower paid, earning on average only 73 to $86 \%$ of the all industry average. The survey data revealing that $85.7 \%$ of operational employees earning $A \$ 30,000$ or less per annum shows that the hotel industry remains a low pay industry and below the average Australian average ordinary weekly time earnings of A\$33,000 reported by the ABS (2002: 2). In addition, the earnings profile is skewed with a gap between high and low waged hotel workers with the majority of operational employees 
(65.4\%) earning less than $A \$ 25,000$ p.a. which is $75.7 \%$ of the average weekly wage at the time of the survey and $13.4 \%$ earning $A \$ 31,000$ or more mostly associated with kitchen trades. The majority of managers (60.0\%) earn A $\$ 49,000$ p.a. or less (ABS survey data, 2000b).

Over the past decade Australia's industrial relations system has shifted from a centralized system of arbitrated industrial awards to a greater reliance on union and non union workplace agreements with awards reduced to the role of setting minimum award conditions. Whilst most large hotels have moved to workplace agreements, wage increases are small varying between $2.5 \%$ and $3.5 \%$ per annum (survey of hotel agreements, work in progress) which is closely in line with movements in the Australian consumer price index. We argue that low pay appears to be linked to jobs which have few skill barriers and are attractive to young workers looking for travel and excitement. There are supply factors at work here with the demand for hotel jobs exceeding supply by almost two to one thus reducing pressure on hotels to either increase wages or reduce labour turnover. This suggests that the award safety net and minimum pay will continue to dominate wage settings and pay structures for the majority of domestic and MNC hotel employees. This is reinforced by ABS data drawn from hotel surveys showing that a majority of hotel workers, or $65.2 \%$ rely on awards for pay setting as compared to an 'all industries' average of only $24.1 \%$. The survey also highlighted the weakness of workplace bargaining structures with only $6.8 \%$ of employees having wage increases set by either union or employee collective agreements. ABS data also suggests weak internal labour markets and poorly internal pay structures with only $28.0 \%$ of hotel employees having access to individual (non registered) performance pay agreements (ABS, 2000b, Table 10).

\section{Working hours:}

Our survey also appraised the number of hours worked per week by operational employees. This measurement was made by recording hours worked on a categorical scale based on five hour increments Findings emanating from this aspect of the research are presented in Table 7 . It is noteworthy that the highest frequency in this distribution is for the "standard" full time working week, i.e., $44.3 \%$ of the surveyed operational employees worked 36-40 hours per week. On a cumulative basis, just over a third of operational employees worked 35 hours or less per week. This underlines the significance of part time and casual work arrangements. From a work/leisure balance perspective, it is noteworthy that about one fifth (or 21.4\%) of the operational employees work more than 40 hours per week and just under $5 \%$ work in excess of a 50 hour week.

Table 7 Hours per week worked by operational employees

\begin{tabular}{|lcc|}
\hline Operational Employees & Frequency & \%* $^{*}$ \\
$0-5$ hours & 8 & 0.5 \\
$6-10$ & 33 & 1.9 \\
$11-15$ & 38 & 2.2 \\
$16-20$ & 98 & 5.7 \\
$21-25$ & 115 & 6.7 \\
$26-30$ & 166 & 9.6 \\
$31-35$ & 134 & 7.8 \\
$36-40$ & 765 & 44.3 \\
$41-45$ & 200 & 11.6
\end{tabular}




\begin{tabular}{|lrr|}
$46-50$ & 88 & 5.1 \\
$50+$ & 82 & 4.7 \\
Total & $\mathbf{1 7 9 2}$ & $\mathbf{1 0 0 . 0}$ \\
\hline
\end{tabular}

*3.6\%

Skills, training and career pathing:

Domestic and MNC hotels represent significant providers of human capital development (Australian Industry Commission, 1996). The survey appraised the incidence of training by asking respondents to indicate the elapsed time since the completion of their last training session. Table 8 presents the findings relating to this aspect of the study. It is significant that almost three quarters (72.1\%) of the operational employees had experienced some training in the year preceding the time of the survey. This suggests a proactive training regime being implemented by the hotels. This view is further supported by the fact that $92.4 \%$ of the operational employees had attended at least one training session in the three years prior to the survey. It is notable that the data collected in this study suggest a similar incidence of training for operating employees and managers. It has been found that $74.5 \%$ of managers had attended a training session in the 12 months preceding the survey and 93.7\% had attended a training session in the prior three months. The measurement instrument used to measure incidence of training has resulted in heavily positively skewed data and a relatively low level of discrimination in the sample. As a result, it is suggested that in future research appraising the same construct, respondents should be asked to indicate the number of months that have elapsed since they last attended a training session. This will provide greater discriminatory power when statistically analyzing the data collected.

Table 8 Time since last training session for operational employees and managers

\begin{tabular}{|lrr|}
\hline Operational Employees & Frequency & \%* \\
$0-1$ years & 1199 & 72.1 \\
$1-2$ & 238 & 14.3 \\
$2-3$ & 99 & 6.0 \\
$3-4$ & 40 & 2.4 \\
$4-5$ & 29 & 1.7 \\
$5-6$ & 11 & 0.7 \\
$6-7$ & 47 & 2.8 \\
Total & $\mathbf{1 7 9 2}$ & $\mathbf{1 0 0 . 0}$ \\
Managers & & \\
$0-1$ years & 105 & 74.5 \\
$1-2$ & 21 & 14.9 \\
$2-3$ & 6 & 4.3 \\
$3-4$ & 2 & 1.4 \\
$4-5$ & 1 & 0.7 \\
$5-6$ & 2 & 1.4 \\
$6-7$ & 4 & 2.8 \\
Total & $\mathbf{1 4 5}$ & $\mathbf{1 0 0 . 0}$ \\
\hline
\end{tabular}

$* 7.2 \%$ of operational employees

$* * 2.8 \%$ of managers

The existence of less tangible costs of staff turnover such as lost quality and reduced efficiency are widely acknowledged, yet very difficult to quantify. The survey data indicates a high frequency of on-the-job training with $72.1 \%$ of operational employees having attended a training session in the 12 months preceding the survey's 
administration. This underlines how staff turnover results in 'skills spillage', necessitating effort directed to in-house training to maintain quality and service levels. This emphasis on training should be set in the context of the high incidence of staff turnover, i.e., the need to replace lost skills resulting from the turnover. This signifies that much of the training budget expended is not resulting in the improvement of the existing human capital stock level, but represents replacement expenditure designed to reduce the staff turnover induced through lost human capital. It is recognized in HR literature that an organizations capacity to innovate and adapt to changing markets depends largely upon the knowledge, competence and expertise of their staff and preventing staff choosing to exit at will is a key HR challenge (Storey, et al. 2002).

The survey also sought data relating to hotel staffs' perceptions on whether more training is warranted. It is interesting that $61.6 \%$ of operational employees felt that no further training was needed, while $72.5 \%$ of managers saw a need for increased levels of training. There is a significant difference their in attitudes. Only $38.4 \%$ of operational employees held the view that they need more training. This is especially pertinent when we recognize that $56.5 \%$ of operational employees said that they experienced 'training fatigue', which raises a question mark over the quality of training provided. If the training provided represented a stimulating experience for the trainee and enhanced their capacity to complete their work, it is hard to envisage the majority declining the opportunity for more training. This interesting finding can also be considered in the context of the high job turnover data reported in Table 5. If operational employees perceive a limited time horizon in connection with the tenure of their current position, they may well see limited merit in further training for the job.

However, for hotel managers, training was seen in a more positive light. Managerial training can be expected to have a distinct focus that relates more to the development of general administrative and managerial skills. Such skills can be viewed as very important in a dynamic workplace environment especially where $64.8 \%$ of managers holding their current position for two years or less. From one perspective this can be seen as positive, as it signifies career development opportunities for ambitious managerial staff, but the quality and depth of their understanding and experience in dealing with customers and employees may be limited due to their limited experience in the hotel underlining the role of multi experiences and qualifications as a 'career fast track' (Harper, Brown and Wilson, 2005). However, from another perspective, in an industry where competitive advantage is based on cost and quality of service, this presents problems. The overall pattern of skill acquisition and job mobility in the hotels studied is consistent with the view that hotel employees acquire skills and competencies through changing employers, not by gradually moving up the organizational hierarchy in the context of a protracted career with one employer.

\section{Labour market developments and HR innovation:}

There are a number of factors that militate against introducing new or innovative HR practices to resolve the apparent irreconcilable differences associated with high turnover, numerically flexible labour, human capital loss, and business performance. With a ready supply of young, willing and educated workers means that in the classical economic sense, the factors that generally accelerate wage bargaining power such as rising skill levels and labour scarcity appear absent. The study found that 
domestic and MNC hotels are not under pressure to pay higher wages. The data collected underscores the link between numerical flexibility, hours of work and persistent low pay. In addition, the lack of job mobility within hotels places training in the role of a 'stop gap' measure designed to halt human capital loss accentuated by employees and managers seeking jobs within industry rather than being able to build careers within the one hotel. No department was ultimately accountable for minimizing turnover and therefore a coherent corrective action plan could not be implemented.

The issue of convergence or divergence of HRM and IR practices and institutions between countries has been a perennial theme pursued in employment-relations research suggesting that MNCs may act as conduits for innovative or new HR practices. Kelliher and Johnson (1997) observe that in relation to the experience of UK hotels at least, 'there is scant evidence of any real shift towards a model of HRM in hotels' (p. 330). These conclusions seem apt at least here. Hotel departments with responsibility for day to day employee decisions serve to weaken HR accountability mechanisms. Entrenched autonomous departmental decision makes more effective employee management systems unnecessary for the time being at least. It appears that the pursuit of innovative HR practices by hotels may in fact represent an unnecessary encumbrance on the pursuit of their competitive strategy. Such strategy is built on an over abundance of young, educated and willing recruits underpinned by basic inhouse training to offset skill losses (see Debrah's 1994 study of the impact of labour scarcity on hotels in Singapore).

According to the ILO, the employment prospects of workers in the international hotel industry will be improved once accountability and effort is directed towards making working conditions in hotels more attractive as a 'prestigious lifetime engagement' through greater training and multi-skilling, creating flatter organizational hierarchies and the subcontracting out of ancillary tasks including improvements in managerial education and training especially in the area of manpower planning (ILO, 2001: 122). The problem is compounded by the fact that large hotels appear satisfied to seek maintenance of the 'status quo' as part of a policy that appears to be driven by the profit maximization economic imperative. This undermines the transmittal role of MNCs with respect to HRM innovations and employee relations practices.

\subsection{Epilogue}

The issue of convergence or divergence of HRM and IR practices and institutions between countries has been a significant on-going theme in employment-relations research. Many scholars have attempted to determine whether convergence is occurring through institutional or workplace arrangements in key economies being transplanted to other countries, largely as a result of advancing technologies and globalisation. The role of MNCs is particularly important in this regard. MNCs and large domestic players also have the capacity to reshape employee relations practices and labour markets. Using two data sources collected from luxury hotels in a selected area noted for its tourism, this study has highlighted the weakness of HR accountability brought about by strong departmentalization perpetuating a labour market that is flexible and low paid and experiencing high turnover; characteristics shared by other low paid industries. However, there is a significant difference: the hotel labour market exhibits relatively high (and seemingly advancing) education 
levels and hotels rely on entry-level training to offset high turnover and job instability and variations in service quality thereby maintain the 'status quo' affording a price based competitive advantage undermining the development of business strategies that encourage HR accountability and innovation. Further research into managerial decision making as between domestic and MNC hotels, accountability mechanisms and better management of human capital would enable hotels to benefit from new opportunities presented by an increasingly educated workforce.

\section{Notes:}

Percentages of missing or invalid data for each Table as follows:

* $\quad$ Percentage of missing data for operational employees

** $\quad$ Percentage of missing data for managers

\section{References}

Atkinson, J., 1984. Manpower strategies for flexible organisations. Personnel Management 16 (8), pp. 28-31.

Australian Bureau of Statistics. 2000a. Tourism Indicators, June Quarter, Cat. No. 8634.0. Australian Government Printing Office, Canberra.

Australian Bureau of Statistics. 2000b. Employee Earnings and Hours, May, Catalogue No. 6305.0, Australian Government Printing Office, Canberra.

Australian Bureau of Statistics. 2002. Average Weekly Earnings - States and Australia, Cat. No. 6302.0. August. Australian Government Printing Office, Canberra.

Australian Bureau of Statistics. 2004a. Education and work, Australia, Cat. No. 6227.0, December, Tables 3 and 6. Australian Government Printing Office, Canberra.

Australian Bureau of Statistics.2004b. Measures of a knowledge-based economy and society, Australia. Occasional Paper. Australian Government Printing Office, Canberra.

Australian Bureau of Statistics. 2004c Tourist Accommodation Australia, Cat. No. 8635.0, March 2004, Tables 3 and 6. Australian Government Printing Office, Canberra.

Barney, J., 1995. Looking inside for competitive advantage. Academy of Management Executive. 9 (4), pp. 49-61.

Chalmers, J., and Kalb, G., 2001. Moving from unemployment to permanent employment: could a casual job accelerate the transition? The Australian Economic Review. 34 (4), pp. 415 - 436.

Debrah, Y., 1994. Management of operative staff in a labour-scarce economy: the views of human resource managers in the hotel industry in Singapore. Asia Pacific Journal of Human Resource Management. 32 (1), pp. 41-60. 
Deery, M., and Jago, K., 2002. The core and the periphery: an examination of the flexible workforce model in the hotel industry. International Journal of Hospitality Management 21 (4), pp. 339-351.

Denvir, A., McMahon, F., 1992. Labour turnover in London hotels and the cost effectiveness of preventative measures. International Journal of Hospitality Management 11 (2), 143-154.

Ferner, A., and Quintanilla, J., 1998. Multinationals, national business systems and HRM: the enduring influence of national identity or a process of 'AngloSaxonisation'. International Journal of Human Resource Management. 9 (4), pp. 710 31.

Guerrier, Y., and Lockwood, A., 1989. Core and peripheral employees in hotel operations. Personnel Review 18 (1), pp. 9-15.

Harper. S., Brown, C., Wilson, I., 2005. Qualifications: a fast-track to hotel general manager? International Journal of Contemporary Hospitality Management 17 (1), pp. 51-64.

Harrington, D., and Akehurst, G., 1996. Service quality and business performance in the UK hotel industry. International Journal of Hospitality Management 15 (3), pp. 283-298.

Haynes, P., and Fryer, G., 1999. Changing patterns of HRM and employment relations in New Zealand: the large hotel industry. Asia Pacific Journal of Human Resources 37 (2), pp. 3-43.

Hofstede, G., 1991. Cultures and Organizations. McGraw-Hill, London.

Hoque, K., 1999. New approaches to HRM in the UK hotel industry. Human Resource Management Journal 9 (2), pp. 64-76.

Hoque, K., 2000. Human Resource Management in the Hotel Industry: Strategy, Innovation and Performance. Routledge, London.

Huselid, M., Jackson, S., and Schuler, R., 1997. Technical and strategic human resource management effectiveness as determinants of firm performance. Academy of Management Journal 40 (1), pp.171-188.

International Labour Organization. 2001.Human Resources Development, Employment and Globalisation in the Hotel. Catering and Tourism Sector, ILO, Geneva, 2001.

Kelliher, C., and Johnson, K., 1997. Personnel management in hotels - an update: a move to human resource management? Progress in Tourism and Hospitality Research, 3, pp. $321-331$.

Kerr C., Dunlop J., Harbison F., and Myers C., 1960. Industrialism and Industrial Man. Oxford University Press, New York. 
Knox, A., 2002. HRM in the Australian luxury hotel industry: signs of innovation. Employment Relations Record 2 (2), pp. 59-68.

Lane, C., 1991. Industrial reorganisation in Europe: patterns of convergence and divergence in Germany, France and Britain. Work, Employment and Society 5 (4), pp. 515-539.

Lepak, D., and Snell, S., 1999. The human resource architecture: toward a theory of human capital allocation and development. Academy of Management Review 24 (1), pp. 31-48.

Littlejohn, D., 1997. Internationalisation in hotels: current aspects and developments. International Journal of Contemporary Hospitality Management 9 (5/6), pp. 187-192.

Lucas, R., 1996. Industrial relations in hotels and catering: neglect and paradox? British Journal of Industrial Relations 34 (2), pp. 267-286.

McGunnigle, P., and Jameson, S., 2000. HRM in UK hotels: a focus on commitment. Employee Relations 22 (4), pp. 403 - 422.

Norris, K., Stromback, T., and Dockery, A., 1995. How tourism labour markets work. Commonwealth Department of Tourism. Research Report No. 1.Australian Government Publishing Service, Canberra.

Orlando, C., Johnson, R., and N. Johnson 2001. Strategic human resource management effectiveness and firm performance. International Journal of Human Resource Management 12 (2), pp. 299-310.

Pfeffer, J., 1994 Competitive Advantage through People. Harvard Business School, Boston, M.A.

Pollert, A., 1988. The flexible firm: fixation or fact? Work, Employment and Society 2 (3), pp. 281-316.

Price, L., 1994. Poor personnel practice in the hotel and catering industry: does it matter? Human Resource Management Journal 4 (1), pp. 44-62.

Ramsay, H., 1997. Fool's gold? European works councils and workplace democracy. Industrial Relations Journal 28 (4), pp. 314-322.

Rowley, C., and Benson, J., 2002. Convergence and divergence in Asian human resource management. California Management Review 44 (2), pp. 90-109.

Sparrow, P., Schuler, R., and Jackson, S., 1994. Convergence or divergence: human resource Practices and policies for competitive advantage world-wide. International Journal of Human Resource Management 5 (2), pp. 268-299. 
Stephen, J., Rowlinson, M., McArdle, L., Hassard, J., Forrester, P., 1994. Flexibility, politics \& strategy: in defence of the model of the flexible firm. Work, Employment \& Society. 8 (2), pp. 221-242.

Stone, K., 1974. The origins of job structures in the steel industry. Review of Radical Political Economics. 6(2), pp.113-173.

Storey, J., Quintas, P., Taylor, P., and Fowle, W., 2002. Flexible employment contracts and their implications for product and process innovation. International Journal of Human Resource Management 13 (1), pp. 1-18.

Timo, N., 1999. Contingent and retentive employment in the Australian hotel industry: reformulating the core-periphery model. Australian Journal of Labour Economics 3 (1), pp. 47-64.

Timo, N., and Davidson, M., 2002. The structure of employee relations in multinational hotels in Australia. In D’Annunzio-Green, Maxwell, G. and Watson, S. (eds) Human Resource Management: International Perspectives in Hospitality and Tourism, Continuum, London, pp. 186-199.

Tourism Forecasting Council. 2001. Tourism and the economy. Forecast, February, pp. 23-24.

World Bank. 1997. Global Economic Prospects and Developing Countries. World Bank, Washington, D.C.

World Tourism Organisation (WTO). 1996. WTO's 1995 International Tourism Overview, WTO, Madrid.

Wright, P., and Boswell, W., 2002. Desegregating HRM: a review and synthesis of micro and macro human resource management research. Journal of Management 28 (3), pp. 247-276. 